\title{
Article
}

\section{Viability of Creating an Offshore Wind Energy Cluster: A Case Study}

\author{
Helena Junqueira ${ }^{1}$, Margarita Robaina ${ }^{1}$, Susana Garrido ${ }^{2}$, Radu Godina ${ }^{3}{ }^{(D}$ and João C. O. Matias ${ }^{1, *(D)}$ \\ 1 GOVCOPP, Unidade de Investigação em Governança, Competitividade e Políticas Públicas, \\ Campus Universitário de Santiago, Universidade de Aveiro, 3810-193 Aveiro, Portugal; \\ catarinajunqueira@ua.pt (H.J.); mrobaina@ua.pt (M.R.) \\ 2 CeBER, Faculty of Economics, Universidade de Coimbra, Av Dias da Silva 165, 3004-512 Coimbra, Portugal; \\ garrido.susana@fe.uc.pt \\ 3 UNIDEMI, Department of Mechanical and Industrial Engineering, NOVA School of Science and Technology, \\ Universidade NOVA de Lisboa, 2829-516 Caparica, Portugal; r.godina@fct.unl.pt \\ * Correspondence: jmatias@ua.pt; Tel.: +351-234-370-361 (ext. 23623)
}

check for updates

Citation: Junqueira, H.; Robaina, M.; Garrido, S.; Godina, R.; Matias, J.C.O Viability of Creating an Offshore Wind Energy Cluster: A Case Study. Appl. Sci. 2021, 11, 308. https://doi.org/ 10.3390/app11010308

Received: 22 November 2020 Accepted: 25 December 2020 Published: 30 December 2020

Publisher's Note: MDPI stays neutral with regard to jurisdictional clai$\mathrm{ms}$ in published maps and institutional affiliations.

Copyright: (C) 2020 by the authors. Licensee MDPI, Basel, Switzerland. This article is an open access article distributed under the terms and conditions of the Creative Commons Attribution (CC BY) license (https:// creativecommons.org/licenses/by/ $4.0 /)$.

\begin{abstract}
Considering the advantages associated with the port sector concerning the potential of offshore wind energy, several international ports are aiming to achieve a solid integration in offshore wind energy clusters. This article performs an analysis of several seaports and offshore wind energy clusters in Europe to assess the feasibility of implementing an offshore wind energy cluster in the Port of Aveiro, Portugal. A deep literature review and a case study methodology were performed. Based on the analysis of the offshore energy market, and of the value chain of the company case study (ASM Offshore), it was concluded that the Portuguese market in this sector is not competitive, compared with other international markets. Nevertheless, the development of an offshore wind energy cluster could increase the included companie's prospects, as well as dispute the growth of other companies associated with this sector. This research is relevant, because there is a lack of research that links the importance of seaports in offshore wind energy projects, in particular with a cluster structure, and because it contributes to knowledge for the development of the Aveiro region and Portugal, based on the exploitation of the renewable energy market and to the increase of related activities.
\end{abstract}

Keywords: renewable energy; offshore wind energy; industrial clusters; seaports; viability study

\section{Introduction}

In view of the exponential growth of the world population that has been observed over the last few years [1], the need to produce greater amounts of energy has gradually become a strong social concern. Moreover, fossil fuels are the main primary energy sources, causing several environmental problems such as global warming, air pollution, acid rain, destruction of the ozone layer, deforestation, and emission of environmental radioactive substances [2]. With this, and prospect that the growth in the use of energy will continue to increase, the adoption of renewable energy sources (RES) has become essential.

Currently, offshore wind farms are located in shallow waters and away from the coast, from marine traffic routes, from strategic naval facilities, and from spaces of ecological interest [3]. Considering the importance of expanding this type of energy in the energy matrix and its contribution to a more sustainable world, away from the use of fossil fuels, more dedication and research is essential for its growth.

Considering the size of the ocean, the use of offshore wind energy can be extended to several areas that are still little explored and may have greater growth potential in relation to other RES. However, the main constraint associated with this type of energy comes from the size and weight of the equipment necessary for its implementation. It must also be considered that a specific transport of this equipment is necessary for offshore wind farms, making the whole process more complex and expensive. 
Considering the wealth and advantages associated with the port sector, both at a strategic level and in terms of freight transport, and bearing in mind the potential of offshore wind energy, several international ports have currently adopted activities associated with this type of energy, especially through the integration in offshore wind energy clusters.

A cluster can be described as a group of industries and other institutions, located in a given geographical area, that establish a partnership and that act towards a common goal, favoring innovation, entrepreneurship, knowledge transfer, better relations between business partners, and more efficient government intervention [4].

Thus, the present work proposes an analysis of the offshore wind energy, with a feasibility study for the implementation of a port cluster of this type of energy, or its "viability". The term "viability" is in this study associated with the identification of the industries/activities related to this type of energy that have taken part in offshore wind energy clusters already existing in Europe and thus evaluate the potential formation of the cluster in the Port of Aveiro. In addition, it is intended to study the feasibility associated with the potential of the Port of Aveiro as a host of the cluster. In addition, a company already headquartered in this entity, ASM Industries, related to the sector under study, will also be evaluated to understand whether this company is an asset for the completion of the cluster. The proposed work proves to be an asset for economic, social, and environmental development in the Aveiro region and for Portugal, allowing for greater energy independence, job creation, and technological and industrial development. Considering the aforementioned, it is considered that the general objective of the proposed work refers to the study of the feasibility of implementing an offshore wind energy cluster at the Port of Aveiro, like a study case, through the use of bibliographic tools.

This paper is organized as follows. In Section 2, a literature review of relevant studies is presented: (i) studies related to the development of RES, especially regarding offshore wind energy and the respective market; (ii) studies on the definition and importance of clusters, as well as the role of clusters in the development of renewable energies; (iii) examples of seaports with activities related to offshore wind energy; and (iv) the policies and initiatives employed to support renewable energies, in particular ocean energies. Section 3 introduces the methodology used and Sections 4 and 5 describe the case study and the implementation study of the cluster in the Seaport of Aveiro. Section 6 presents and discusses the results, and Section 7 concludes and presents the limitations and future studies suggestions.

\section{Literature Review}

There are two main problems associated with conventional energies: first, the associated pollution, which contributes to unknown changes in the global climate; second, the fossil fuels used are not renewable, and can irrefutably be exhausted [5]. In view of this, it is extremely important to manage resources more efficiently, through changes in energy consumption, supported by more sustainable sources that cause fewer environmental and social impacts [6].

Considering these challenges, renewable energies appear as the most viable option, in order to avoid high levels of greenhouse gases (GHG) in the atmosphere, through the development of a more sustainable type of technology, which enables a cleaner environment, better access to electricity, and less pressure on non-renewable natural resources [7].

Regarding the participation of RES in global energy consumption, despite the high growth rates that have been observed, this type of energy still represents only a small part in the energy mix. Based on the 2019 report from the Renewable Energy Policy Network for the 21st Century [8], it was concluded that RES contributed only about $18.1 \%$ to the total final energy consumption in 2017. In this percentage, modern energies provided $10.6 \%$ of the final consumption, while the traditional use of biomass represented the rest of the energy mix with $7.5 \%$. Much of the modern renewable portion was produced by thermal energy $(4.2 \%)$, followed by hydroelectric energy $(3.6 \%)$ and other RES, including wind, solar, biomass, geothermal, and ocean energy $(2 \%)$. 
According to [9], the percentage of renewable energy production has increased in most countries around the world. Throughout 2018, several targets for renewable electricity production were achieved. In Europe, the United Kingdom achieved annual records in the production of wind energy onshore $(9.1 \%)$ and offshore $(8 \%)$. For the first time, the European Union (EU) produced more than $15 \%$ of its annual electricity from wind and solar energy. Modern renewable energies achieved high percentages of production in Denmark (51\%), Uruguay (36\%), Ireland (29\%), Germany (26\%), and Portugal (24\%) and, in general, at least nine countries produced more than $20 \%$ of its electricity from renewable energies [8].

Regarding Portugal, according to the report by Deloitte Consulters S.A., in 2019, RES contributed, on average, about $56 \%$ of the total electricity production in mainland Portugal. In April 2020, according to Portuguese Association Of Renewable Energy (APREN), RES supported around $72.1 \%$ of total electricity production in mainland Portugal, again with greater production from hydropower (38.4\%), followed by wind power (25.3\%) [10].

\subsection{Wind Energy}

Wind energy is the conversion of energy from wind into useful energy. This process of obtaining energy requires that the kinetic energy of the moving air be converted into mechanical energy and then into electrical energy through the use of wind turbines [11].

Currently, there are two distinct forms of wind energy, onshore and offshore. Onshore wind energy is the oldest and most common due to its proximity to the population. On the other hand, offshore energy has been developed in recent years and has proved to be an asset for the production of energy from RES, as in the sea there is access to wider areas, with higher wind speeds [12].

Like any RES, wind energy is seen as a clean, ecological, inexhaustible source and emits few toxic residues, contributing daily to the reduction of GHG emissions. All forms of energy have an environmental impact; however, impacts related to wind energy are generally less problematic than impacts associated with other energy sources [13].

Today, wind energy is considered the most competitive technology in terms of cost in most renewable energy markets [14-16], and according to the Global Wind Energy Council (GWEC), its growth is due to several reasons, including: (a) the maturity of the industry; (b) the technology development, with the implementation of a new generation of turbines (higher and more efficient), and (c) growing investor confidence. The mentioned factors have contributed not only to the growth of wind energy at an industrial level, but also to encouraging researchers and investors to apply efforts in this type of energy. This aspect creates benefits in terms of employment, generates economic growth, and contributes to energy independence and security in the electricity sector [12].

In 2019, the total wind power capacity in Europe was 205 GW, representing 15\% of the electricity consumed by the EU-28. In this year, Europe installed 15.4 GW of new wind power capacity, representing $27 \%$ more than in 2018, but 10\% less than the 2017 record. Despite lower values compared to 2017, the year 2019 had a considerable impact on this form of renewable energy, considering the drop in costs per kilowatt-hour (kWh), which made wind energy the lowest cost option for new energy production capacities. As a result, the economy of wind energy has increased worldwide, making this the main factor for new installations [17].

\subsubsection{Offshore Wind Energy vs. Onshore Wind Energy}

The main difference between onshore and offshore wind installations is in their respective production environments. In the following paragraphs a comparison is made between onshore and offshore wind farms, demonstrating some of the clear advantages and disadvantages of both types of wind energy [12,15,18-21].

One of the advantages of offshore wind energy comes from the quality of the wind resource at the sea, as the turbine is placed at an ideal height to use the maximum wind intensity. In addition, winds at sea are typically stronger and more stable, producing more 
energy per installed unit. This production increases with the distance to the coast, where the wind is more uniform, leading to fewer turbulence effects.

Another advantage of offshore wind energy is related to the space available on land for the development of onshore wind energy, which has become increasingly limited. The ocean is the largest portion of the planet and is an area with much to explore, where wind farms can be installed. Moreover, the marine environment allows for a more efficient transport of the resources needed for energy production, as well as the installation of larger wind turbine units, achieving greater production per unit of installation.

In general, the environmental impacts associated with technologies for the production of this type of energy are lower for offshore wind farms than for onshore wind farms. With regard to visual and acoustic impacts, offshore wind turbines are less invasive than onshore turbines, as their apparent size and noise can be attenuated by the distance to the coast. Thus, it allows a greater exploitation of resources, with larger equipment and greater rotation speed, making it possible to use more efficient geometries with thinner cables.

However, marine biology can be affected by the structures placed in this environment. Although at onshore level there is also this type of impact, especially on birds, the placement of this equipment in the ocean changes a large part of the system, causing a higher impact. Another disadvantage related to offshore wind energy comes from the construction, assembly, and maintenance of structures, as they are more complex activities to be carried out compared with onshore structures. Nevertheless, this disadvantage contributes to the creation of more jobs during installation and exploration, which can be considered a positive factor, even though it causes more costs for developers of offshore wind farms. In addition, this energy has the possibility to take advantage of the infrastructures of other marine resources to produce electric energy, such as wave and tidal energies in mixed installations.

The costs of the licensing process are more stringent, and the engineering methods and phases of operation are more expensive than onshore. In offshore wind farms, the cost of wind turbines, towers, and foundations is also much higher, which can be explained, mainly, due to the high costs of maritime operations. In addition, fixed or submersible platforms are required for the marine environment, as well as the construction of longer electrical networks, considering that, generally, there are no marine electrical infrastructures that connect the higher areas of wind resources to consumer centers, also leading to greater costs.

There is a need for more developed offshore wind farm technology. This is essential for wind turbine generators, which are subjected to high loads and must adapt to the marine environment, where there is a faster degradation of this equipment and, therefore, they must be prepared for corrosion conditions. However, the use of the various equipment and the associated costs, will largely depend on the weather conditions, the waves, the depth of the water, and the distance to the coast.

Another disadvantage refers to the accessibility restrictions and the difficulties existing in foundations, in maritime operations, and in the construction and operation phases. Moreover, the limited roughness of the sea surface means that the propagation of turbulence is higher at sea than on land.

As has been seen throughout this topic, the offshore wind sector is a field with potential growth. However, offshore investments differ greatly from onshore. Planning is more complex and time-consuming, construction and maintenance require new solutions, and connecting to the network is a rigorous process. In conclusion, offshore wind farms are an innovative business area, but immature and high risk, which requires technological development and high investment by large companies in the sector.

\subsubsection{Offshore Wind Energy in the World}

The offshore wind sector has grown exponentially since 1991, when the world's first offshore wind farm was built off the coast of the city of Vindeby, Denmark [22]. This park consisted of 11 offshore wind turbines, with a unit capacity of 450 kilowatts $(\mathrm{kW})$, making a total installed capacity of 4.95 megawatts (MW) [13]. 
Between 1991 and 2001, several experimental projects were carried out, with the construction of several offshore wind farms operating in the EU (Table 1). The different models of wind turbines and different types of foundations were tested. Wind turbines of 450 to $600 \mathrm{~kW}$ of nominal capacity were used for these projects, with distances up to $7 \mathrm{~km}$ from the coast and depths up to $10 \mathrm{~m}$ [12].

Table 1. First offshore wind farms operating in the European Union (EU). (Adapted from [12]).

\begin{tabular}{ccccccc}
\hline Year of Installation & Project Location & $\begin{array}{c}\text { Installed } \\
\text { Capacity (MW) }\end{array}$ & $\begin{array}{c}\text { Number of } \\
\text { Turbines }\end{array}$ & Water Depth (m) & $\begin{array}{c}\text { Distance to } \\
\text { Coast (km) }\end{array}$ & $\begin{array}{c}\text { Wind Turbine } \\
\text { Manufacturer }\end{array}$ \\
\hline 1991 & Vindeby, Denmark & 4.95 & 11 & $2.5-5$ & 2.5 & Bonus \\
1994 & Lely, Holland & 2 & 4 & $5-10$ & 0.75 & Nedwind \\
1995 & Tum Knob, Denmark & 5 & 10 & $0.8-4$ & 6 & Vestas \\
1996 & Irene Vorrink, Holland & 16.8 & 28 & 2 & 0.03 & NordTank \\
1998 & Bockstigen, Sweden & 2.8 & 5 & $6-8$ & WindWorld \\
2000 & Blyth, United Kingdom & 3.8 & 2 & 6 & Vestas \\
2001 & Middelgrunden, Denmark & 40 & 20 & $5-10$ & $2-3$ & Bonus \\
2001 & Utgrunden I, Sweden & 10.5 & 7 & $4-10$ & GE \\
\hline
\end{tabular}

In 2002, one of the largest offshore wind farms so far was built in the North Sea, located at Horns Rev, Denmark. This park consisted of 80 Vestas wind turbines, producing an installed capacity of $160 \mathrm{MW}$. The construction of Horns Rev I was a very important step in the establishment of the offshore wind industry, given that it was the first park to make use of many technologies, which have since become standard in the offshore wind industry.

Since 2007, offshore wind energy has been growing vigorously, with a progressive increase in the size and power of equipment, as well as in increasing the distance from the coast and the use of higher depths, contributing to a total of more than 30 wind farms offshore in the EU in 2008 [18].

At the beginning of 2011, 1247 wind turbines were operative, corresponding to 49 wind farms, in nine European countries [23].

In 2012, offshore wind energy gained importance and experienced growth worldwide, marked by a $10 \%$ representation of this type of energy produced in Europe. This year, it contributed about $4100 \mathrm{MW}$ worldwide, where about $1 / 3$ were produced in Europe, especially in the United Kingdom, Germany, Italy, Spain, Sweden, and France [24].

The year 2017 was the most relevant year for this sector for various reasons, including the development of the project for the first offshore wind island, which significantly increased the total installed capacity in Europe. Additionally, new economic regulations were introduced, which encouraged investment by countries such as Germany and the Netherlands. This year was also marked by the expansion of offshore wind energy in northern Europe, later extending to Asia, North America, and other countries [16].

At the end of 2017, this type of energy was already installed in the ocean waters of eleven European countries, with approximately $84 \%$ (15,780 MW) of all offshore wind farms in the world. Of the remaining 16\%, a large part was in China, followed by Vietnam, Japan, South Korea, and the USA [16].

By the end of 2018, 17 countries (11 in Europe, 5 in Asia, and 1 in North America) had offshore wind capacity. The United Kingdom maintained its leadership at full capacity (8 GW), followed by Germany (6.4 GW), China (4.4 GW), Denmark (1.3 GW), and Belgium (1.2 GW) [25].

In 2019, this type of renewable energy had a $24 \%$ share in new installations in Europe, with a record $3627 \mathrm{MW}$ of new capacity connected to the grid. About half of the installations were in the United Kingdom, with an installed capacity of $1764 \mathrm{MW}$, and the rest in Germany (1111 MW), Denmark (374 MW), Belgium (370 MW), and Portugal (8 MW) [25].

Currently, more than 100 offshore wind farms are active in Europe [26], including the Hornsea One offshore wind farm, located in the North Sea, in the United Kingdom, with a capacity of $1218 \mathrm{MW}[25,27]$. 
With regard to Portugal, it presents a coastal platform with depths ranging between 25 and $200 \mathrm{~m}$ and it is considered that the topographic characteristics of the Portuguese coast and offshore are favorable to the implementation of offshore systems, especially for offshore wind energy floating type [23]. The first offshore wind farm installed on floating platforms in Portugal, started from the Wind Float 1 project, which was connected to the grid at the end of 2011. This project was installed on the Portuguese coast, near Aguçadoura, and used the design and construction of a demonstration unit using a $2 \mathrm{MW}$ commercial turbine. The park operated for 5 years, producing more than 17 Gigawatt-hours (GWh), in a sea with a depth of more than $7 \mathrm{~m}$ and with waves greater than $17 \mathrm{~m}$ [28].

\subsubsection{Offshore Wind Energy Market}

It is important to note that one of the most relevant aspects for the development of offshore wind energy is the technology with which it is associated. Today, the offshore wind energy market comprises a large range of investors: utility companies, equipment manufacturers (OEMs), contractors (engineering, construction, and installation), independent energy producers, infrastructure funds, and institutional investors [29].

The construction of offshore wind farms can be organized in several industrial segments and is dominated by some companies in each sector. Noteworthy are the companies that produce offshore wind turbines, foundations, wind towers, cables (between arrays and grid connection), construction companies, and installation companies.

Over the past few years, there has been an increase in the technological market for components for offshore wind energy production, leading the industry in this sector to become increasingly competitive [25]. Increased competitiveness in the sector and, consequently, increased competition, have contributed to reducing manufacturers' profitable margins, even in some of the largest production companies in the world. This aspect has resulted in a reduction of the sale prices of several products, with repercussions on the movement of offshore wind energy to new markets, increasing the sales of its technologies.

Currently, ten main offshore wind turbine manufacturers stand out, which in 2018 won an $85 \%$ share of the entire market.

The main companies involved in the wind turbines supply chain are described in Table 2.

Table 2. The main companies in the offshore wind turbine market.

\begin{tabular}{|c|c|c|}
\hline Components Produced & Company & Country \\
\hline \multirow{6}{*}{ Main manufacturers [8] } & Vestas & Denmark \\
\hline & Goldwind & China \\
\hline & Siemens Gamesa & Spain \\
\hline & GE Renewable Energy & United States \\
\hline & Envision & China \\
\hline & Enercon & Germany \\
\hline \multirow{4}{*}{ Wind turbine installers [30] } & A2Sea & Denmark \\
\hline & Van Oord/MPI & Netherlands \\
\hline & Fred Olsen Wind Carrier & Norway \\
\hline & Seajacks & United Kingdom \\
\hline \multirow{6}{*}{ Offshore wind developers [30] } & GeoSea & Belgium \\
\hline & Ørsted & Denmark \\
\hline & Vattenfall & Sweden \\
\hline & E-on & Germany \\
\hline & Iberdrola & Spain \\
\hline & Innogia & Germany \\
\hline \multirow{5}{*}{ Foundations market—steel companies [30] } & EEW & Germany \\
\hline & SiF Tecade & Netherlands \\
\hline & Bladt Industries & Denmark \\
\hline & Smulders JV & Belgium \\
\hline & Windar Renovables & Spain \\
\hline
\end{tabular}


Table 2. Cont.

\begin{tabular}{|c|c|c|}
\hline Components Produced & Company & Country \\
\hline \multirow{4}{*}{ Installers of turbine structures [30] } & van Oord/MPI & Netherlands \\
\hline & GeoSea/Deme & Belgium \\
\hline & Boskalis Seaway Heavy Lifting & Netherlands \\
\hline & SPT Offshore & Netherlands \\
\hline \multirow{6}{*}{$\begin{array}{l}\text { Offshore wind towers companies, among } \\
\text { others, stand out [30] }\end{array}$} & KGW Schweriner & Germany \\
\hline & Welcon & Denmark \\
\hline & Titan Wind & Denmark \\
\hline & GRI Towers & Spain \\
\hline & Cs Wind & United Kingdom \\
\hline & Navacel & Spain \\
\hline \multirow{4}{*}{ Cable manufacturers between arrays [30] } & JDR & United Kingdom \\
\hline & Nexans & France \\
\hline & Prysmian & Italy \\
\hline & Norddeutsche Seekabelwerke GmbH & Germany \\
\hline \multirow{4}{*}{ Network connection cables [30] } & NKT & Denmark \\
\hline & $\mathrm{ABB}$ & Switzerland \\
\hline & Nexans & France \\
\hline & Prysmian and Norddeutsche Seekabelwerke GmbH & Italy \\
\hline
\end{tabular}

\subsection{The Role of Clusters in the Development of Renewable Energies}

Michael Porter defined industrial clusters as "geographical concentrations of companies, institutions and other entities, which are relevant with respect to competition, which cooperate with each other and manifest themselves in a specific field or sector" [31]. According to the author, these companies can be customers, government institutions, and other entities, such as universities, professional training institutions and even trade associations. This varied set of institutions allows acquiring greater supply or transfer of knowledge, better relationships, and trust, as well as the spread of technical information.

The competitive advantages of an industrial cluster were discussed by Marshall, (1925) [32], who highlighted three main explanations: (i) with an industrial cluster, the companies come together geographically, which contributes to a more efficient resources management, with the development of a set of specialized and highly qualified labor for the specific needs of the sector; (ii) the companies that make up the cluster can provide specific information for a given sector with geographical proximity, and the various members can achieve economies of scale in the development of a service, as well as the use of common technologies or an infrastructure capital for all companies, and (iii) companies that come together geographically can acquire relevant information and ideas for the growth of the sector in which they are involved and can establish cooperative relationships to achieve a common goal. This concept facilitates the integration of knowledge between companies and promotes trust and personal interactions between economic agents, which become stronger.

Porter [31] found that although geographic proximity is an important point in the interconnection of the companies that make up the cluster and a source of advantage in terms of competition, it is not seen by itself as a source of competitive advantage. Indeed, with globalization and speed of transportation, it is possible for companies of any location to obtain anything, from anywhere, at any time. Thus, it was inferred that the success of the industrial cluster depends, not only on the geographical positioning, but also on the conditions of the sector at a competitive level, on the technological innovation of the products or services, and on the interaction processes between the various parts that constitute the business.

According to Fundeanu and Badele (2014) [33], the long-term performance of the industrial cluster depends on the attraction of companies, venture capital, new skills, and other external resources. The same author concluded that certain clusters generate high costs; how- 
ever, these stand out, mostly, due to sustainable innovation, resource development, and strong commercial relationships that occur inside and outside the cluster area.

With the increase in competitiveness in the field of renewable energies and the intensive growth of this market, more and more companies are trying to find advantages that make them distinct and superior. Considering the referred advantages associated with clusters, it was considered that they are a way for the growth of most companies in this sector, worldwide.

In order to assess competitiveness in the renewable energy industry and to understand the importance of the cluster approach for this sector, an analysis based on the "Porter's Diamond" model was used. To carry out this research (Figure 1), several articles were used [34-36].

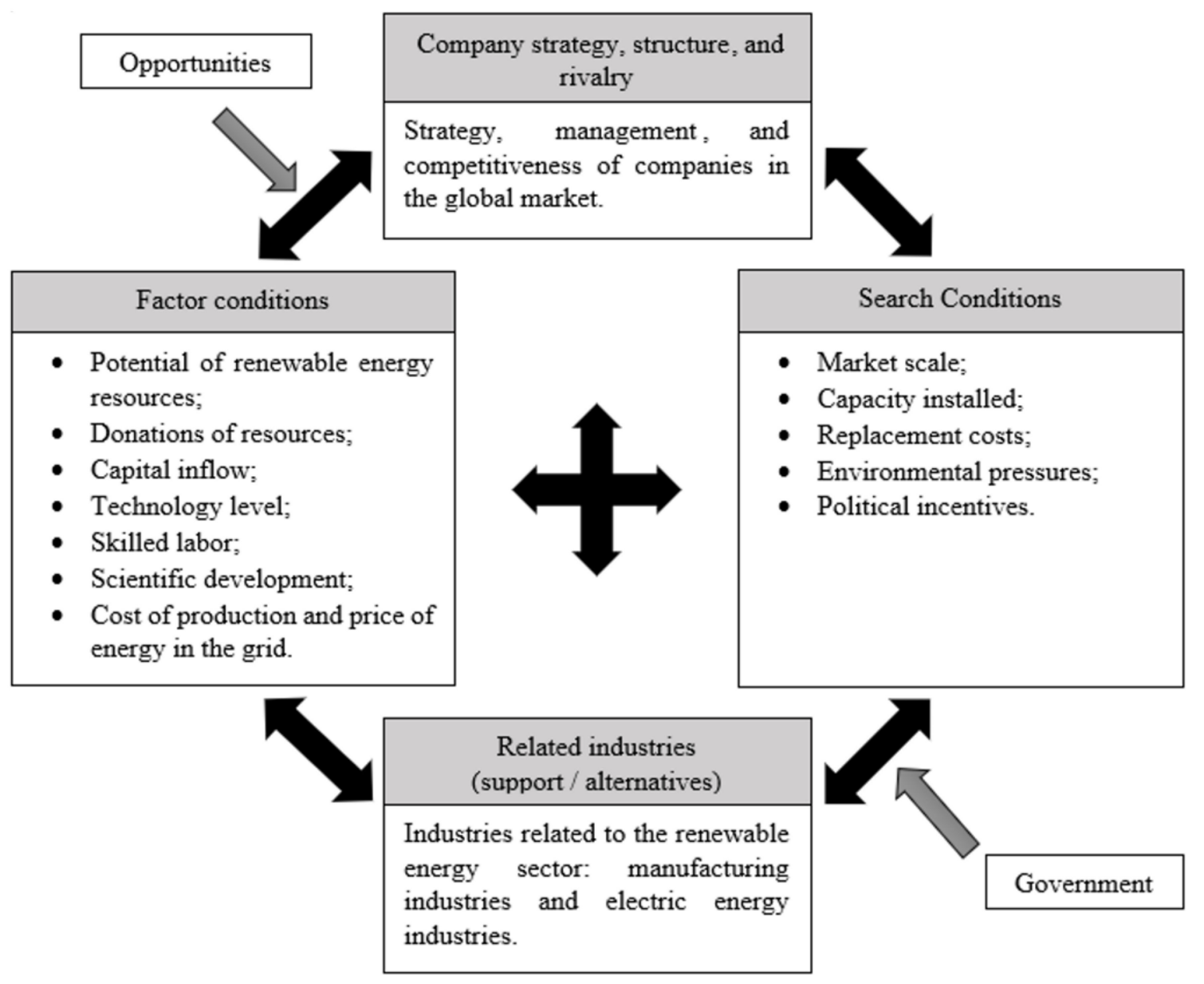

Figure 1. Porter's Diamond model with application in renewable energies.

Considering the scheme presented by Figure 1, it is considered that concerning the "factor conditions", resources are a fundamental factor for the development of the companies in this sector. That is, in general, the more abundant the resources for the production of energy from RES, the greater the potential for development. Furthermore, capital investment is essential for the development of the activity at a technological and scientific level. The technical level is also one of the main factors for the progress of this activity, given that advanced technologies can significantly increase productivity, decrease costs, and solve energy storage problems. Labor force is indispensable, as without this factor it would be impossible to carry out any stage of energy production. Finally, another essential aspect in this attribute of the model refers to the high costs of production and the high prices of energy, since they are two main obstacles to the wide commercialization of this product. 
Regarding the "demand conditions" attribute, these include several factors, such as the size of the market that influences product prices, since, if market capacity increases, product prices decrease because of competitiveness. Another factor refers to the installed capacity, which the higher it is, the greater the energy production. Environmental pressures are also a factor assessed when using a given service, and regarding the production of renewable energy, this is seen as a beneficial and important activity for this pillar of sustainability. Finally, it is considered that public policies also influence demand perspectives in this sector, since governments tend to stimulate investment through policy instruments to accelerate the commercialization of RES technologies.

The "related and support industries" refer to companies belonging to the renewable energy market, such as the manufacturing industry, which influences all companies producing the technologies for converting this type of energy and the electricity industry, which interferes with the use of energy in its converted form. A superior and favorable industrial environment drives investment in renewable energies and contributes to the technological development of this sector.

The "strategy, structure, and rivalry of the company" refers essentially to the structure and management of companies related to the renewable energy sector, as well as the performance of competitors. The more effective the company's strategy, the more vigorous and competitive the industry will be. Likewise, the more intense the competition, the more efficient the allocation of resources. Thus, it can be concluded that these attributes play an irreplaceable role in the competitiveness of the sector.

The "opportunities" and "government" are affected by the entire system that constitutes the model. The influence of the government lies mainly in creating the opportunity for the development of this activity. As a rule, the government exercises its influence over the RES through the implementation of public policies, such as the obligation for electricity quotas, financial subsidies, tax incentives, tax exemptions, and trade and carbon tax.

Considering the analysis through Porter's model, it was possible to collect information about the main factors that influence the competitiveness of the renewable energy sector and that are important to achieve success. Regarding the approach in relation to clusters, it is considered that its creation can become an advantage in the implementation of this type of energy and contribute to the exploration of the sector, as the installation of any system related to this form of energy requires high financial support, technological development, and a more vigorous and competitive structure and strategy. With the development of this type of business partnership, cooperation between various stakeholders is created, both in terms of sharing resources, materials, and equipment, as well as in sharing knowledge and other relevant services. This aspect contributes to a more efficient management of financial resources, as well as to the collection of information and ideas by the various entities, leading to better results, with a reduction in production costs.

According to [37], technologies, specialization of resources, information, marketing, and the needs of consumers make up the cluster. In the technological perspective, the cluster appears in the relationship that is established between individuals through the exchange of knowledge in the perspective of technological innovation [38] necessary for the realization of a territorial dynamic. Technological systems must bear in mind several situations: the creation and dissemination of knowledge, the supply of capital resources and skills, the creation of positive externalities in the market, the formation of an energy market, and a positive relationship between suppliers and consumers of technology [39]. The energy cluster is a sum of several actors that interact with each other in an energy distribution system, in which qualifications, decision-making, financing, and the market itself are promoted. Technology is a determining factor in the development and transformation of energy. The use of technologies in renewable energies is important and constitutes an investment decision factor in companies. Variables such as Information Systems and Technologies (ITS) infrastructure (existence of a network between the various organizations), IT assets (capital invested in ITS), and software (ITS innovation) are important for obtaining competitiveness and cooperation between companies [40]. In the case of 
offshore energies, as it is a sector in rapid expansion and where companies are in an initial cooperation/collaboration phase, the use of technology is still insignificant compared to other types of renewable energy. However, investments in this type of energy are based on two points; on the one hand they are directed towards the specialization of ITS and human capital, and on the other hand, they depend on the energy policy followed in each country where offshore energy parks are implemented. When considering that we are dealing with an innovative sector and that technologies are used to promote its development, we are considering that there is a transfer of knowledge between the various participants [41].

As seen, clusters are industrial agglomerations that produce benefits in each territory where they are located. Therefore, the key elements in the development of an offshore wind energy cluster are associated with: (i) the cooperative relationship between companies; (ii) the transfer of technology and knowledge between the aggregate sectors; (iii) the national and international political factors; (iv) the economic and financial issues associated with the location and the partners; (v) the environmental issues, since offshore wind energy is considered renewable, so it contributes to the reduction of pollution in the atmosphere, even though it may have an impact on the marine environment; and finally, (vi) the social sphere, considering that the creation of this type of project sometimes needs social support to move forward. Several examples of industrial clusters in the renewable energy sector across Europe can be mentioned: Renewable Energy Hamburg in Germany; IBN Offshore Energy cluster, Belgian Offshore Cluster, and Blauwe cluster in Belgium; Breizh EMR and RACE (Rhône-alpes cutting EDGE) in France, Energy Innovation Cluster in Denmark; Cluster Energía (Basque energy cluster) and Enercluster in Spain; Norwegian Offshore Wind Cluster in Norway; Offshore Wind Scotland, offshore ECOWinds, and Team Humber (Marine Alliance) in the United Kingdom; and Offshore Väst in Sweden.

\subsection{Cases of Seaports with Offshore Wind Energy Activities in Europe}

Today, the seaports offerings typically consist of several complementary services, such as goods handling services at port terminals, towing services, piloting services, and industrial services. Moreover, the port aims at local and regional development, can offer test facilities, training centers, rental warehouses, offices and operation centers for manufacturers, and also enables a supply chain [42].

Currently, several ports are expanding their business to support renewable energy, in sectors such as offshore wind energy. These entities adapt their infrastructures through the development of more sophisticated and effective ways to meet the components (e.g., wind turbines) and vessels with increasing dimensions, in order to provide cost reduction and an increase in efficiency [42].

Regarding the various types of seaports and the type of port associated with each part of the offshore wind energy production process, a study by Enamorado (2016) [43] was considered. According to the author, the type of port used for the development of offshore wind energy activities will depend on the installation strategy adopted, the cost analysis, the distance from the manufacturing centers to the wind farm, and the distance from the coast to it. As shown in Table 3, the selection of the most appropriate port for the development of each activity depends, in large part, on the project phase for which the ports will be used, whether in the installation phase or in the operation phase and maintenance of the offshore wind farm.

Analyzing Table 3, it is possible to infer that a seaport can be an asset for the offshore wind energy production process. The management of all stages at the local and temporal level is essential for the profitability of the activity developed. Although the main function associated with the port is the transportation of various equipment from land to the sea, there are already some ports with the function of manufacturing and assembly, which raise the potential of this activity in these entities. 
Table 3. Types of ports.

Port Type

Port of imports/exports

Port of manufacture

Mounting port

Port of mobilization

Offshore port

Operation and maintenance port

Research ports
Activity

Reception of components from manufacturers on the ground, which are handled and stored for later loading on ships, which will transport them to ports intended for manufacture and assembly.

Manufacture of equipment such as turbines, foundations, and offshore wind cables.

Pre-assembly of the components (turbines and foundation units) received from the factories.

Loading of turbines components and foundation units already pre-assembled, in vessels, to the offshore wind farm where they will later be installed.

Multipurpose offshore terminals that enable a reduction in installation and transportation costs, as well as a decrease in response time for the maintenance of wind farms.

Provide the offshore wind farm with support services for operation and maintenance.

These ports must be located at a relatively short distance from the park to reduce travel time for employees, minimize the use of parts, and optimize working times on site. Areas for offshore prototypes, test turbines, training, and instruction facilities.

Ports located in the North Sea and the Baltic Sea represent important strategic ports for the construction of offshore wind farms in European waters [23]. For the proposed study, it was considered relevant to investigate and analyze the main European seaports, where activities related to offshore wind energy are carried out. Figure 2 shows the main ports related to offshore wind energy in Europe. As can be observed, most of the European seaports associated with offshore wind energy are located in the north, in particular near the North Sea.

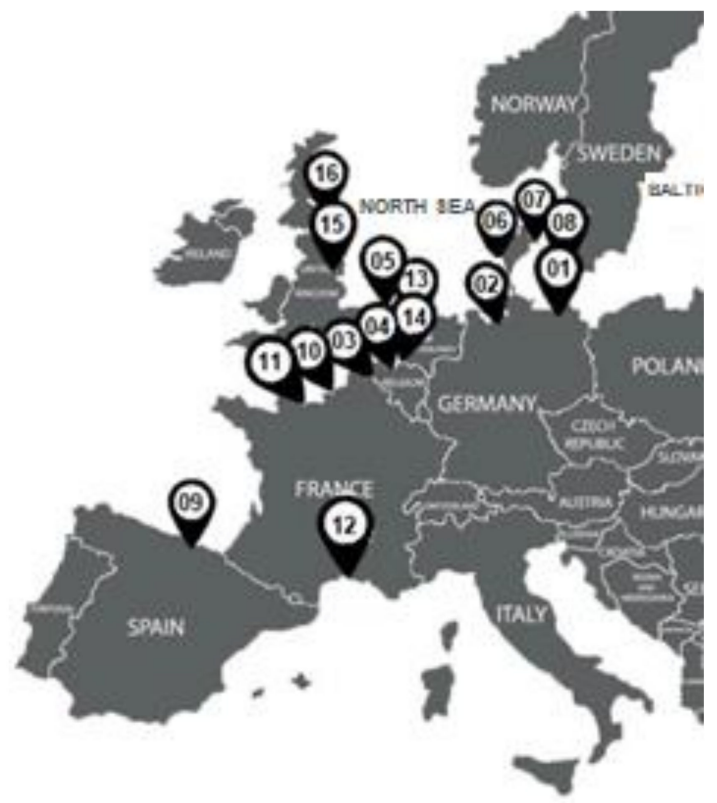

Figure 2. Map with the main seaports related to offshore wind energy in Europe. Legend: 1-Port of Rostock; 2-Port of Cuxhaven; 3-Port of Ostend; 4-Port of Zeebruge; 5-Port of Antwerp; 6-Port of Esbjerg; 7-Port of Grenaa; 8-Port of Rønne; 9-Port of Bilbao; 10-Port of Dieppe; 11-Port of Le Havre; 12-Port of Fos Sur Mer; 13-Port of Amsterdam; 14-Port of Vlissingen; 15-Green Port Hull; 16-Port of Blyth.

The Port of Rostock is the largest and deepest port in Germany, located in the southern part of the Baltic Sea. This port provides services throughout the supply chain of the wind industry, from the manufacture of components to the logistics and handling of structures related to the sector, such as towers, shovels, pipes, and foundations for projects in the North Sea and the Baltic Sea. One of the examples of manufacturers in this sector is the 
company Nordex, which has been in this port since 1994, supplying all types of wind turbine components [44].

The Port of Cuxhaven, Germany, is located in a favorable transport location, at the maritime crossroads between the North Sea and the Baltic Sea. In this port, an offshore base was built to produce and ship all the necessary components for offshore wind turbine generators. In recent years, more than 80 million euros have been invested in this offshore infrastructure and, in addition, private investors from the offshore industry have invested more than 100 million euros during 2007 and 2008. This port, since mid-2017, also has a platform heavy cargo offshore in the vicinity of the offshore base and, recently, Offshore Terminal 2 was built, intended for offshore wind energy installations, previously produced in the vicinity of the port [45].

In Belgium, the Port of Ostend, has been involved, since 2008, in the development of offshore wind farms in the North Sea. In order to solve the sector's demands, the investment company REBO NV was founded in this port, at the REBO Terminal, and since then, several projects have been carried out and an offshore wind network has been developed. Currently, this port is dedicated to the exploration of a 15-hectare offshore terminal, where vessels from offshore installations and warehouses with direct access to the open sea are carried out [46].

The Port of Zeebruge, Belgium, extended its external port and chose wind energy to produce green electricity, as did the Port of Antwerp, which has already been involved in various projects associated with this sector [47].

The Port of Esbjerg located in Denmark, on the North Sea, is considered the leader in Europe in terms of handling and transporting offshore wind energy. It is referred to as the main European port in the development of this activity, since 4/5th of the offshore wind capacity installed in Europe has been shipped from this port, in particular Horns Rev I and Horns Rev II, as well as wind farms foreign offshore, Butendiek, Northwind, Sandbank, Dantysk, Humber Gateway, and Westermost Rough. This port has specialized facilities and flexible areas for transport, pre-assembly, shipping, and maintenance of offshore wind turbines. In addition, the companies that make up the Port of Esbjerg represent the entire supply chain of the wind industry, including several of the world's leading companies specializing in handling and maintaining wind installations [48].

The Port of Grenaa, also located in Denmark, is one of the main seaports in this country with capacity for offshore wind turbine projects. This port was responsible for supplying turbines to the Anholt offshore wind farm and currently has space available for the long-term storage of offshore wind projects [49].

The Port of Rønne, located in Denmark, is surrounded by the Baltic Sea, which is considered one of the seas with the greatest potential for pre-assembling structures for offshore wind farms. This is a reference port for some of the pioneering wind turbine companies, such as Siemens Gamesa and Vesta [50].

The Port of Bilbao, in Spain, received the first operation of offshore wind turbines in 2013 [51] and, since then, it has grown exponentially in the operations associated with this energy activity. In 2006, a leading renewable energy company (Acciona) opened an offshore wind farm near this port ("near shore"), with a system of five Siemens Gamesa turbines.

The Port of Dieppe, due to its location and contact with the Dieppe channel, is considered the best French port in the Normandie region for the development of offshore wind energy. This port has experience acquired in the unloading of wind turbine parts and is considered one of the most competitive ports in this sector in France. This aspect is due to the space available outside and at the commercial port for maintenance and logistics activities related to the sector, in addition to the Port of Dieppe offering a service for mooring, vessel maintenance, towing, piloting, and dredging. This port has recently been linked to the development of the offshore wind farm in Dieppe (Le tréport), developed by three business groups Dieppe-Navals, Dieppe Meca Energies, and Vialog, that have invested in the success of this long-term project [52].

Regarding the Port of Le Havre, Siemens Gamesa and HAROPA (Port du Havre) signed an agreement to establish an offshore wind turbine factory in this seaport. The plant will 
occupy a 36-hectare plot and will be used both to produce shovels, nacelles, and generators, as well as to support installation activities. It will mainly supply the three French wind farms, in Saint-Brieuc, Yeu-Noirmoutier, and Dieppe-Le Tréport, but it will also be able to manufacture facilities for the French, European, and world markets. This project is expected to start in mid-2020 and will create around 750 jobs [53,54].

The Port of Fos Sur Mer is a French port that is also directed to several projects related to the offshore wind energy sector, such as storage and transport of components.

The Port of Amsterdam is located in the Netherlands, between the English Channel and the North Sea. Due to its location, space, layout, and infrastructure, this is considered an ideal place for offshore activities, in terms of installation, production, and maintenance. Over the past few years, several wind farms have been installed through the Port of Amsterdam, such as Princess Amalia, Egmond aan Zee, Luchterduinen, and Westermeerwind. Recently, this port was involved in the installation of the Fryslân wind farm that will be installed in November 2020. Currently, the Port of Amsterdam together with the Port of IJmuiden are carrying out the Energiehaven project, referring to the creation of an energy cluster to serve as a basis for the construction and maintenance of offshore wind farms. This cluster will be located in an unused dredging deposit in Averijhaven, a site with about 15 hectares of land to be explored. The new energy port will play an important role in intensifying space and strengthening port infrastructure [55].

Furthermore, in the Netherlands, the Verbrugge terminal (Port of Vlissingen), together with the Belgian company Sarens (world leader in lifting and transporting heavy loads) formed a strategic partnership, resulting in a synergy of know-how and capacity, related to offshore wind energy. Both partners signed an exclusive contract to work intensively on all logistics related to offshore wind farms. The Verbrugge terminal is considered a leader in logistics services, located in the economic center of northwest Europe, on the North Sea coast, at the entrance to the Western Scheldt estuary. Due to its excellent location, this terminal is ideal for providing logistics services for large-scale offshore projects in the North Sea.

Another structure that has contributed to the development of offshore wind energy is the ABP (Association of British Ports). This network consists of 21 ports in Great Britain that offer sea, road, and rail access. ABP is considered a fundamental organization for the development of new facilities and for the provision of personalized services to attend various aspects of the development, maintenance, and operation of offshore wind farms. One of the examples of ABP's work is at Green Port Hull, where an investment of more than $£ 310$ million was made between this organization and Siemens Gamesa [56].

The Green Port Hull holds a position of excellence to capitalize on the UK offshore wind industry and these attributes are the reason why Siemens Gamesa chose this seaport as the location for the construction of its blade manufacturing, assembly, and maintenance facilities and world-class offshore wind turbines, which is currently the core activity of this [57].

Other ports in the UK, such as Grimsby, Barrow, Lowestoft, Swansea, Casco, and Southampton, have also grown as the main offshore wind operation and maintenance centers, through support provided by ABP.

The Port of Blyth is also located in the United Kingdom and is one of the British ports most involved in activities related to offshore wind energy. Considering its vast experience in the wind sector, the port is well positioned to serve various services in the offshore wind sector, with the development of parks such as Dogger Bank, Seagreen, and Hornsea. In addition to the availability of services related to wind farms, this seaport focuses on the research of renewable offshore energy and has an area for the dismantling of offshore equipment [58].

In Portugal, there are no seaports associated with offshore energy production yet. The port activity plays an important role for the Portuguese economy and for the creation of jobs, since it constitutes support to several activities, functioning as points of interconnection in the logistics and international transport networks. Additionally, these infrastructures 
allow the development of exports, as it contributes to facilitating the integration of national industries in international markets [59].

The main function of Portuguese seaports is essentially commercial, and they are classified according to the volume of cargo handled and their capacity. The continental port system can be divided into nine commercial ports, five of which constitute the main port system-Ports of Leixões, Aveiro, Lisbon, Setúbal, and Sines, and the remaining four are part of the secondary port system-Viana do Castelo, Figueira da Foz, Faro, and Portimão. Of these, and with regard to the volume of general cargo handled, the Port of Sines stands out, followed by that of Leixões, Lisbon, Setubal, and Aveiro [59].

\subsection{Offshore Wind Energy Policies and Initiatives}

Over the past few years, several policies and initiatives have been employed with regard to offshore wind energy and, consequently, have been contributing to its development. According to Semedo (2018) [60], policy associated with offshore wind energy should cover five major areas: government and fiscal support, quota-based incentives, availability of the specific location, capital for investment, and the construction of an ecosystem favorable to R\&D.

The EU has established several measures that support the development of this type of energy, including the recent Ocean Energy Strategic Roadmap report. This document, prepared by the European Commission, highlights that EU members must invest in creating conditions for the development of ocean energy technologies, namely by reducing the risk associated with investment, simplifying licensing, and establishing the best test sites for the pre-commercial launch phases [61].

The different policies that support renewable energies, such as the Paris Agreement, the EU25 energy policy, and national policies, have contributed to an increase in demand for sites to produce offshore wind energy. However, policies related to the electricity market regarding the distribution of energy at sea and on land, could further stimulate the production of this type of energy. Furthermore, cooperation between sea and regional basins could encourage multiple interconnections and the development of a network with new transnational development zones. Another aspect is related to the policy to stimulate the multiple use of offshore wind energy jointly with recreational activities, such as fishing and aquaculture, since this aspect can change the planning and design criteria of an offshore wind farm, as well as the farm.

Regarding the process of implementing an offshore wind farm, all steps, such as planning consent, selection, design, and location, must be in accordance with local, national, and European policy. Regarding the actors that support the production of offshore wind energy, we highlight WindEurope (European Wind Energy Association), ENTSO-E (European Network of Transmission Systems Operators), and Europacable (Europe's leading cable producer). With regard to the initiatives that have supported the prospection of offshore wind energy, we highlight those described in Table $4[23,62]$.

Table 4. Initiatives for the development of offshore wind energy.

\begin{tabular}{|c|c|}
\hline Initiative Name & Brief Explanation of the Initiative \\
\hline $\begin{array}{l}\text { Political declaration on energy cooperation } \\
\text { between North Sea countries }\end{array}$ & $\begin{array}{l}\text { It aims to further strengthen the energy cooperation of countries in the North Sea region, with } \\
\text { regard to offshore wind energy. }\end{array}$ \\
\hline $\begin{array}{l}\text { Good Practice WIND (Intelligent } \\
\text { Energy Europe) }\end{array}$ & $\begin{array}{l}\text { It explains the barriers to the development of onshore/offshore wind production, with objectives } \\
\text { for renewable energies, as well as the active involvement of communities in the development and } \\
\text { implementation of these measures. }\end{array}$ \\
\hline The North Sea Grid Project & $\begin{array}{l}\text { It is a research project funded by Intelligent Energy Europe, on the implementation of an offshore } \\
\text { network in the North Sea. }\end{array}$ \\
\hline $\begin{array}{l}\text { The North Seas Countries Offshore Grid } \\
\text { Initiative (NSCOGI) }\end{array}$ & $\begin{array}{l}\text { North Sea Countries offshore network initiative, with the development of a regional cooperation } \\
\text { of } 10 \text { countries, in order to facilitate the coordinated development of a possible offshore electricity } \\
\text { network in the North Sea area. }\end{array}$ \\
\hline Friends of the Super Grid (FOSG) & It aims to create policies for the construction of a European energy distribution super-network. \\
\hline
\end{tabular}


In Table 5, the policies and good practices that have contributed to the development of offshore wind energy are presented [63].

Table 5. Policies and good practices for the implementation of offshore wind energy.

\begin{tabular}{|c|c|}
\hline Policies & Good Practices \\
\hline Renewable electricity standards & $\begin{array}{l}\text { Establish long-term RES goals, which develop over time, to support the } \\
\text { growth of wind energy. } \\
\text { Development of offshore wind technology. } \\
\text { - Support for a political environment that facilitates the implementation of } \\
\text { technologies for the production of wind energy. }\end{array}$ \\
\hline Food charges & $\begin{array}{l}\text { Differentiation of Wind Feed-in Tariffs (FIT) payments in relation to resource } \\
\text { quality, project size, and offshore wind development, and in relation to } \\
\text { applied technology. } \\
\text { Consider bonus payments and premiums to support broader wind } \\
\text { development objectives. } \\
\text { - Consider the regression of Wind FIT prices. }\end{array}$ \\
\hline $\begin{array}{l}\text { Interconnection standards and net metering } \\
\text { for distributed wind energy }\end{array}$ & $\begin{array}{l}\text { - } \quad \text { Establish interconnection standards. } \\
\text { - } \quad \text { Consider a wind grid measurement policy. }\end{array}$ \\
\hline Wind investments and production tax credits & $\begin{array}{l}\text { - } \quad \text { Establish an incentive rate. } \\
\text { - } \quad \text { Support for a stable policy environment. } \\
\text { - } \quad \text { Consider the tax credit for wind production and the tax credit for } \\
\text { wind investments. } \\
\text { - Support non-taxable entities. }\end{array}$ \\
\hline $\begin{array}{l}\text { Additional approaches to support } \\
\text { private investment }\end{array}$ & $\begin{array}{l}\text { - } \quad \text { Identify competitive wind energy zones. } \\
\text { - } \quad \text { Reduce capital risks and costs. } \\
\text { - Simplify licensing processes. }\end{array}$ \\
\hline
\end{tabular}

Based on the table presented, it is considered that among the various mechanisms used to encourage the introduction and development of wind energy, fixed remuneration tariffs (FIT) represent the most frequently used. This form of incentive has been applied in several European countries and has been a successful mechanism in stimulating investment in these technologies. In addition to this process, there are other relevant tools for the growth of this type of energy, such as tax incentives, which stimulate the involvement of the national supply chain, and simplification of the licensing process, which makes it possible to reduce the time and complexity of energy implementation processes.

Considering the licensing, it is known that for the installation of devices for offshore wind energy production, in the case of a public maritime domain, it is necessary to apply for an installation and use license. These types of procedures are stipulated by the Water Framework Directive (WFD), Directive 2000/60/ EC of the European Parliament and of the Council, of 23 October 2000, which establishes the bases for the national institutional framework, based on concept of watershed management. With regard to the ordering of the maritime space in relation to activities, these are regulated by Planning of Space and Maritime Activities (POEM) [23].

It can be stated that public policies and initiatives play a relevant role in all stages of development of the various renewable energies, from the initial stage of support to R\&D, to financial support in the first demonstration and pre-marketing projects, as well as in the incentive market research and performance of the installation and maintenance phases.

\section{Methodology}

Considering the nature of the present work, several research methods were sought in order to respond to the proposed objectives. To this end, exploratory research was carried out based on scientific articles collected through various scientific platforms, such as the Web of Science, Scopus, and Google Scholar. In obtaining this information, keywords 
were inserted according to the topic under study (global warming; wind energy; offshore wind energy; renewable energy; sustainable development; energy growth; energy market; energy policy; public policy; sea policy; innovative industrial cluster; Diamond model; industry competitiveness; seaports; development) and a selection of the most relevant and reliable articles was carried out to obtain the most scientific work possible. In addition, secondary sources based on credited reports and some more relevant websites for the topic addressed were used and market analyses of the sector in question were carried out, as well as analyses of its possible stakeholders. Following these tasks, an analysis of the competitiveness of a cluster of renewable energies was carried out, using the "Porter's Diamond" model, in order to evaluate the strategy, structure, and rivalry between the companies in the industry, the related industries and support, demand conditions, and factor conditions. For the analysis of the partner entity of the study (Port of Aveiro) and the case study company (ASM Industries), several analyses were carried out in order to obtain all possible information about its supply chain, using data provided by the entities themselves.

\section{Case Studies-Seaport of Aveiro in Portugal and ASM Offshore Case Studies Description}

The seaport of Aveiro is located in the district of Aveiro, inserted in a lagoon that constitutes the Ria de Aveiro. This is considered a competitive, effective, and sustainable port. It has excellent levels of productivity, responding to the most varied challenges. Being a recent port infrastructure, it has a well-ordered and integrated area, currently having 7 specialized terminals with about $4 \mathrm{~km}$ of wharf and 2 intermodal logistics zones [64].

The Port of Aveiro is well positioned, with a railway infrastructure connected to the railways of the Trans-European Transport Network. Considering the road access, the highways are lightly congested and connect the port to the main cities in the country and Spain. In addition to the various specialized terminals targeted at the various industrial sectors that the Port of Aveiro has, it also has an 80-hectare maritime logistics and industrial zone called ZALI (Zone of Logistics and Industrial Activities) (multimodal port logistics platform integrated in the Port of Aveiro) which is located in the northern sector of the port.

ASM Industries is a holding company created in 2007 within the A. Silva Matos Group, a Portuguese metalworking industrial group, founded in Sever do Vouga, in 1980. Over the years, the A. Silva Matos (ASM) group has operated fundamentally in sectors such as food, oil, and gas, through the manufacture of storage tanks and other steel and pressure equipment. In addition, it has applied efforts in logistics solutions, such as road tanks and containers for sea and rail transport. This holding company decided to apply its knowledge and invest in manufacturing capacity, job creation, and projects related to renewable energies.

In this sequence, the creation of ASM Industries arose, with the objective of creating industrial capacity and diversifying the group's activity in the renewable energy sector. This holding company operated particularly in the wind energy industry, through the development of steel structures, such as wind towers and offshore foundations, and also in the marine renewable energy sector (waves and tides) and offshore aquaculture, through the design of marine structures. Based on the experience of this company in the sale of metal equipment, ASM Industries has positioned itself as a reference supplier, with high levels of quality and competitiveness across Europe.

With the growth of this group in the market for equipment for the production of wind energy, in 2007, ASM Energia was invited to join the consortium ENEOP (Eólicas de Portugal), in which it had to invest in a new manufacturing unit specialized in wind towers for onshore application. During the next five years, the company saw growth and success, with a social and economic impact, fulfilling all its sales objectives. In this section, we intend to investigate the potential of the Port of Aveiro, as a welcoming entity for an offshore wind energy cluster, considering the market for this energy, as well as the types of clusters and seaports related to it. 
Furthermore, considering the location of ASM Offshore at ZALI in the Port of Aveiro and the fact that it is a company that belongs to the offshore renewable energy sector, it is included in this work as a case study. With the analysis of this company, it is intended to infer what its position is in the offshore renewable energy market and what the advantages of its presence in the Port of Aveiro are, in order to envisage the benefits of the port in hosting a group of companies in the same branch for the formation of the cluster. ASM Offshore serves as an anchor to the Port of Aveiro considering the offshore wind energy market, given that it has knowledge, high technology integrated in this activity and has the ability to influence business decisions and the location of several companies, qualified suppliers and customers, required for the formation of the cluster.

Considering the pioneering spirit and success on the part of this company, the opportunity arose to join a new European consortium, "Windplus". This consortium has developed a project known as "WindFloat", previously referred to in the "Offshore Wind Energy Market" section. The project was based on the development of a semi-submersible and floating platform, where a wind turbine was installed to produce offshore wind energy. In this project, the ASM Industries Group was responsible for the construction and supply of the prototype platform of the referred project for testing.

Recently, in 2018, ASM Industries signed a new contract with this consortium, for the supply of two Windfloat platforms for a pre-commercial project in Viana do Castelo, with high power wind turbines (8.5 MW).

Considering the evolution of the markets and in order to meet the needs of customers, the opportunity arose to found ASM II Offshore Industries, S.A., hereinafter referred to as ASM Offshore. This subsidiary of the holding company ASM Industries was founded in 2015 and its main objective is to monitor trends in the offshore wind energy market, as well as to create favorable conditions for the supply of large metal equipment for application in new offshore wind farms.

With this transition, ASM Industries started to split into ASM Energia and ASM Offshore, having two manufacturing units. As regards ASM Energia, its plant is located in Sever do Vouga and is responsible for the production of onshore and tubular wind towers. This sub-holding produces more than 25,000 tons of steel and more than 640 sections of onshore towers per year. ASM Offshore is headquartered in a concession area in the Port of Aveiro (ZALI), and in this plant, offshore wind towers and foundations are produced. In 2018, the company invested more than 30 million euros, and began to develop these structures in 2019.

Considering the objective of the developed study, it was considered essential to analyze the current business cycle of ASM Offshore, as well as the global business cycle in which ASM Offshore is inserted, in order to envision which are the best companies to interact with, and how the fact that these companies are established in the Port of Aveiro can benefit this entity, as well as the company in question. Regarding the ASM Offshore value chain and considering the environment in which it operates in the renewable energy sector, a general analysis of the value chain of the offshore wind energy market was carried out.

Regarding the inputs associated with this process, all materials that allow obtaining the outputs are considered, which in this particular case, refers to obtaining the offshore wind turbine for energy production. Thus, it is assumed that the inputs related to this activity are the structures that make up the wind turbines, such as wind blades, wind towers, foundations, rotor, and generator, among others; as well as the components that form these structures, such as steel, cables, paints, screws, and supports, among others.

In relation to the life cycle phases of the entire process, all activities that contribute to its implementation are considered, namely manufacture of the wind turbine components; turbine construction, assembly, and installation services; transportation of the various equipment; maintenance of wind farms and dismantling at the end of the structures life cycle.

There are several companies responsible for these processes by which the raw material is moved and transformed until the final product is obtained. In Figure 3, information 
about the value chain associated with the technological market for offshore wind energy is presented in a succinct way.

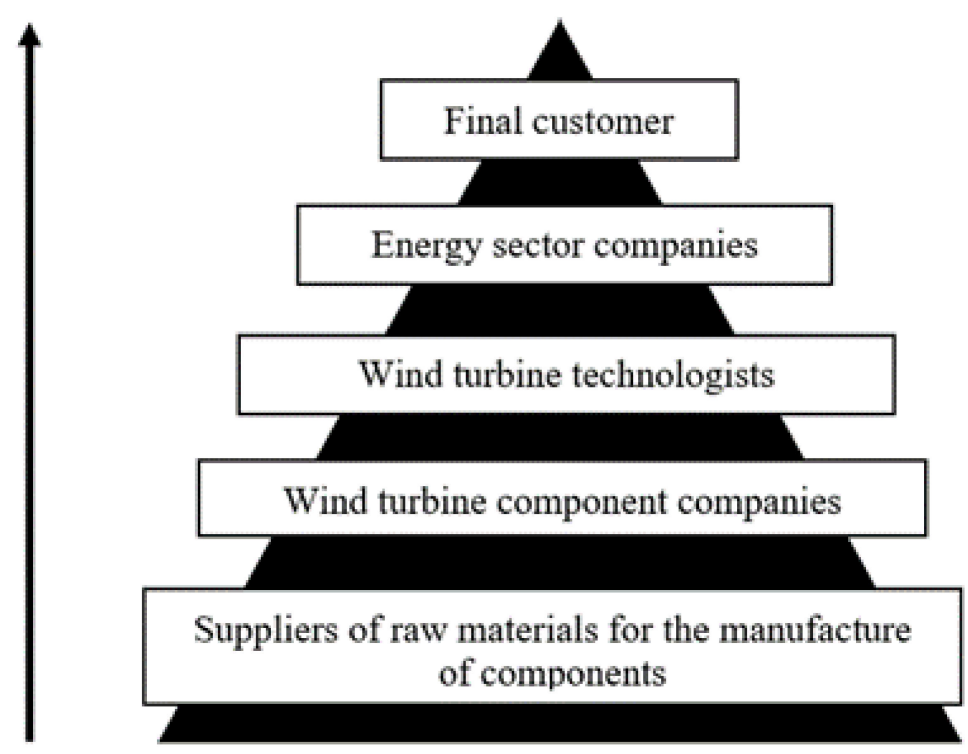

Figure 3. Value chain of the offshore wind energy market.

ASM Offshore emerges as one of the companies that supply some of the main components for the process previously analyzed, through the supply of wind towers, usually supplied to technologists, and offshore foundations, usually supplied directly to the end customer or installers $[65,66]$.

The market associated with a company, from its suppliers and customers to its competitors, directly affects its positioning and influences its competitive advantage in relation to other companies in the same sector. Considering that ASM Offshore acts as an anchor for the Port of Aveiro, with regard to the intended cluster, a deeper analysis of the various stakeholders becomes relevant.

Considering the market previously analyzed, in relation to this company's potential wind tower customers, Enercon, Senvion, GE Wind Energy, Siemens Gamesa Acciona, and Nordex stand out. About the offshore foundations, the main players and potential customers are Ortersd, Vattenfall, EDP, RWE, DEME, Van Oord, Saipem, SHL, Kyaerner, Smulders, Lamprell, PrinciplePower, and WindPlus.

Regarding the suppliers of raw materials that can integrate the products manufactured by ASM Offshore, this information is shown in Table 6.

Based on Table 6 it is possible to infer that most potential ASM Offshore suppliers are international. Through this assertion, and based on the literature review, it is possible to deduce two possible alternatives: (i) there is no specialized national market related to the offshore energy sector that can meet the needs of national companies; or (ii) the international market offers better quality/price products that justify your purchase to international companies, with increased transport costs and fees. This perspective allows us to infer that there is no national market for this sector, competitive with international networks. The main competitors of this company are some of the institutions related to offshore wind towers and foundations. 
Table 6. Raw material suppliers for ASM Offshore.

\begin{tabular}{ccc}
\hline Type of Product & Company & Country \\
\hline \multirow{2}{*}{ STEEL } & Ancofer/Dilinger & Netherlands/Germany \\
& Metinvest Trametal & Italy \\
& POSCO & South Korea \\
& NLMK & Denmark \\
\hline \multirow{2}{*}{ FLANGE } & Taewoong & South Korea \\
& Euskal Forging & Spain \\
& Barranquesa & Spain \\
\hline \multirow{2}{*}{ INK } & Hempel & United Kingdom \\
& Jotun & Norway \\
& SIKA & Germany \\
& CIN & Portugal \\
\hline SECONDARY STEEL & Mostostal Pomorze & Poland \\
& Aluship & Poland \\
& Rometal & Netherlands \\
& Aluwind & Denmark \\
\hline TRANSPORT & Laso & Portugal \\
& Actanis & Spain \\
& Burmester & Portugal \\
& Coordinadora & Spain \\
& Core Marine & Norway \\
& OHT & Norway \\
\hline
\end{tabular}

\section{Implementation Study of the Cluster in the Seaport of Aveiro}

Based on several studies related to the implementation of industrial clusters [67-69], the advantages added to the Port of Aveiro were verified.

As seen throughout this work, clusters are seen as close concentrations of companies that communicate and cooperate with each other to achieve a common goal. For the creation of this type of group, an appropriate organizational structure is essential, as well as the answer to several questions that are imposed at the initial stage of the project, such as: (1) What is the vision/mission and objective of the cluster? (2) How will the objectives be achieved? (3) Who will be the partners/members for the cluster? (4) How will the various partners belonging to the cluster be organized? (5) What are the internal rules and processes that the team will use to maintain control? (6) How will they deal with competitive pressure? (7) What will the role of commercial activities in the cluster be? (8) How quickly should members be integrated? (9) How important is the government for the creation of the cluster? (10) What are the funding sources for the cluster's prosperity? and (11) What is the strategy to be implemented and how will it be adjusted for the future?

Based on the answer to the initial questions of project orientation, a structured and well-defined plan regarding the implementation of the cluster must be drawn up, similar to that carried out in the scheme of Figure 4.

Initially, a solid planning structure should be implemented. This approach guides the process and sequencing of tasks and actions, ensures that all elements of research, analysis, and evaluation are fulfilled, and allows monitoring and structured control of the process as it progresses. 
Implement a structured planning structure.

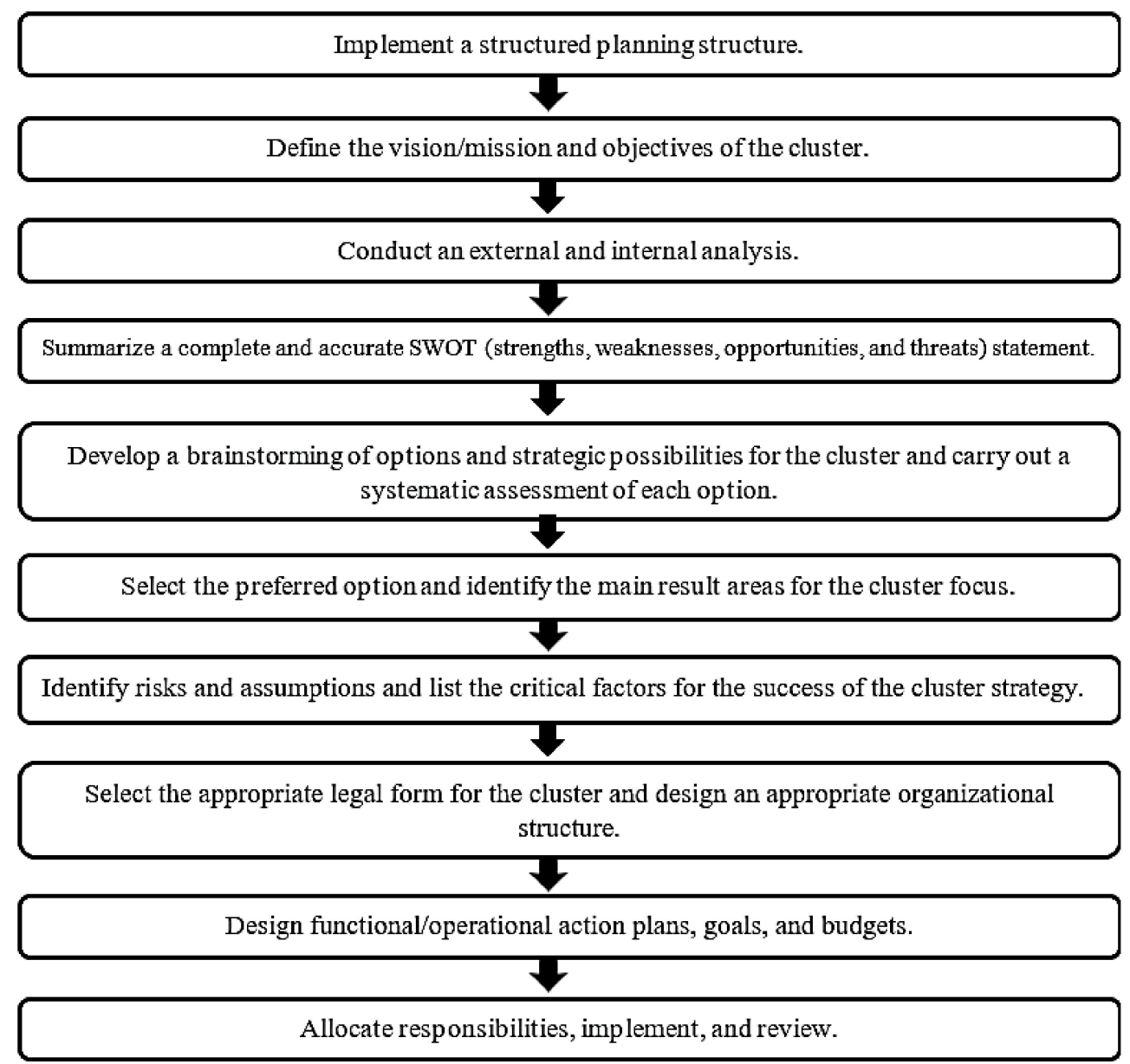

Figure 4. Scheme with guidelines for the implementation of a cluster.

After defining the objectives of the cluster, several analyses should be performed, such as that of PESTEL, Porter's forces, McKinsey 7S Framework analysis, SWOT analysis, among others. These analyses allow the identification of the strategies to implement in the cluster and an evaluation of the options (costs, benefits, advantages, and disadvantages), for a targeted and beneficial selection of companies. Regarding PESTEL analysis, it is focused on the study of macro-environmental factors (political, social, economic, technological, environmental, and legal) for a business activity [70]. Moreover, this analysis allows framing the entity that may receive the cluster, in order to understand its potential for the development of the project. Regarding Porter's forces, five forces should be considered: rivalry between competitors; business power of buyers; bargaining power of suppliers; entry of new competitors; and substitute products. These forces should be studied in order to assess and analyze the external environment in which the organization is inserted [37]. In relation to the McKinsey 7S Framework analysis, it is often used as an organizational analysis tool to assess and monitor changes in an organization's internal situation. The model is based on the theory that, for an organization to perform well, it is necessary that seven elements (strategy, structure, systems, shared values, skills, human resources, and style) are aligned and reinforce each other. Therefore, the model can be used to help identify what needs to be realigned to improve performance or to maintain alignment during other types of change [71,72]. The SWOT analysis is a strategic planning technique used to assist organizations in identifying strengths, weaknesses, opportunities, and threats related to business competition or project planning [73-75]. For the specific case of the implementation of an offshore wind energy cluster in the Port of Aveiro, [76] present a SWOT analysis, concluding that the fact that this entity has a large logistics area can be an important advantage for the development of the cluster, in the sense that it allows the 
installation of several plants, as well as important centers of scientific development. In addition, quality overland and decongested accesses are seen as an important advantage for the development of the companies that make up the cluster, with good availability, both at sea and on land. The good quality equipment available through the port can facilitate the transport of the various materials that make up the technologies for producing offshore wind energy, which, as we have seen throughout the article, have considerable weight and dimensions.

Subsequently, a list of questions must be drawn up, the risks analyzed, and the critical factors listed in order to explore the cluster's organizational situation and select the most viable option. After the strategy has been defined and the questions answered, legal advice about the legal formation of the cluster should be sought. In addition, several factors must be considered that condition the cluster's development and, consequently, its success. First, it is necessary to obtain more specific information in relation to the costs associated with the creation of the clusters, as well as what part of the costs must be borne by the private sector and how much the support from the public sector will be. With this premise, the question arises of what the role of public entities will be in the development of this type of initiative that supports the prospecting of renewable energies. In order to answer these matters, research related to the development of the sector, weighting analysis, and the benefits of the creation of this industrial group and the search for financing, both by public and private entities, are necessary.

With regard to partnerships, associations and municipal councils are relevant to the promotion of the cluster, both in terms of funding and in terms of visibility. It was also concluded, based on the section referring to the analysis of public policies, that aspects related to renewable energies have been receiving a greater importance in society and also the policies applied to this sector. In short, these types of actions that support the progress of renewable energies support the local economy and contribute to the country's development.

The government is one of the essential entities in the different stages of the formation of a cluster. It can assist by guiding the cluster mapping process, as well as stimulating innovation and entrepreneurship with the development of business, innovative, and institutional environments that are vital for the success of a cluster. In addition, it can contribute through financing or creating facilitating policies, strategic action plans, and having trained public sector employees.

The Port of Aveiro and the renewable energy sector are regulated, respectively, by the Ministry of Infrastructure and Housing and the Ministry of the Environment and Climate Action, therefore, it is necessary to outline a well-structured project for both ministries, in order to bid for support from them, belonging to the constitutional government, which, as it turns out, are fundamental to the creation of the cluster.

Another relevant aspect refers to the type of companies that make up the cluster. An essential condition for the development of this type of group concerns the presence of companies that are competitive in the various markets associated with the sector. Thus, when it is intended to create a cluster, one must consider competitiveness indicators, such as a high level of efficiency of companies and sectors of the cluster; a high level of export of goods and services; and high economic indicators of the activities associated with the various companies. In addition, the existence of competitors associated with the various markets seems to be a strategic advantage for the development of the cluster.

Based on the objective of the present study and the supply chain related to offshore wind energy, it can be deduced that wind turbine companies, offshore foundations, steel and hydraulics, as well as offshore wind energy developers, consultancy, and transport would be relevant to the formation of the cluster. With regard to the Port of Aveiro, it already has a foundation production company (ASM Offshore), which is an advantage for the development of the cluster. Moreover, this entity enjoys a good maritime transport network that is seen as an asset for the formation of offshore wind farms.

Still related to this factor, it is considered that the growing recognition of the importance of universities and research institutions as centers of collective learning and knowledge 
transfer agencies with regard to the development of new technologies and structures to support the various levels of government. It is believed that the presence of these types of companies contributes to the integration of theoretical perspectives with empirical evidence and to the constant innovation in the offshore wind energy sector, which, as it turns out, is a sector in constant change. Innovation increasingly depends on a close interaction between the scientific base and the commercial sector, since the degree of connectivity between knowledge agents and the companies that develop the activity is an essential aspect for obtaining a high-level innovation system.

The competitive advantages of the region where the cluster is formed were also considered a relevant point. A good geographic location, professionals in human resources, a favorable transportation network, suppliers of available components, appropriate services, specialized educational establishments and programs, and a strong economy are factors that favor the competitiveness of the territory and lead to high investments.

Regarding these factors, the region of Aveiro is considered one of the most economically dynamic Portuguese districts. It has a firm socio-economic and business structure, with companies and sectors based on activities with a high technological potential and an intensive workforce, as well as sectors that bet on tradition and new industrial and technologically evolved investments.

The industrial zones are in excellent locations, associated with the proximity of large urban centers, making this region innovative, competitive, and attractive to national and foreign investors [77].

One of the most significant aspects of this analysis comes from the geographical concentration and proximity of the companies that make up the cluster. If the main members of the clusters are very close to each other, in geographic terms, competitive advantages and opportunities for active cooperation are created. The geographic scale can vary according to the type and particularities of each cluster and can include several entities that contribute to its development. Considering the concessioned area by the Port of Aveiro to host the cluster, this aspect becomes an advantage for this entity, since it allows the reception of countless companies from the most varied sectors and allows the creation of a geographical concentration that can enhance the development of the sector.

The diversity of the members of a cluster is also seen as a significant factor. The cluster can consist of companies of various types and degrees of importance; however, all companies have a relevant role within the cluster and contribute to its progress.

As regards the Port of Aveiro, it is important to identify which are the potential companies to be included in the offshore wind cluster. For this, it is essential to carry out an analysis of these companies, in order to see which are the ones that create the most value and benefits, and are fundamental for the final implementation of the cluster. In addition, it is essential to establish a well-defined strategy between the different companies, a diversified business network, and strong cooperation between the members of the cluster. For this, a coordinated decision-making mechanism must be introduced and observed.

Finally, in order to obtain a high-performance system, the connections and interaction between the members of the cluster are also considered, since one of the main success factors for the development of these clusters, refers to the availability of work connections and the coordination of efforts between the various members.

\section{Results and Discussion}

Wind energy has the most cost competitive technology in the various renewable energy markets. The onshore wind segment is the most common and used; however, considering the advantages of the offshore environment, this has been an option in recent years. It was concluded that the main motivations for prospecting in the marine environment are the availability and quality of the wind resource at sea, since the space available and unexplored is high and, generally, the winds are stronger and more uniform, allowing the use of larger equipment that raises the level of energy production. Nevertheless, the implementation of offshore technologies is more expensive than onshore, the planning 
process is more complex and time consuming, construction and maintenance require more effective solutions, and the grid connection and licensing process is rigorous.

Regarding the type of technology for offshore wind energy production, it was found that fixed-bottom turbines represent the most evolved and have been the most used to produce this type of energy. However, the industry has begun to invest in the implementation of floating turbines, which offer a potential for expansion into viable and economically attractive areas. In relation to Portugal and considering the topographical characteristics of the Portuguese coast, it was considered that this is favorable to the implementation of offshore systems, especially for floating type offshore wind energy.

The literature review showed that there was an increase in the sector's competitiveness and, consequently, an increase in competition, which has converged on a reduction in the sales prices of the various products, resulting in a movement of offshore wind energy to new markets, increasing the sales of its technologies. Regarding offshore wind turbine manufacturers, Vestas, Goldwind, Siemens Gamesa, GE Renewable Energy, Envision, and Enercon stood out.

The market analysis of this type of energy, together with the analysis carried out on the value chain of the company case study (ASM Offshore), led to the conclusion that the Portuguese market in this sector is not competitive with international markets. The development of a cluster of this type of energy in Portugal, with the various companies belonging to each category, could boost its prospects, as well as dispute the growth of other companies associated with the national sector.

The importance of clusters in the growth of the renewable energy sector is recognized, since the installation of any system related to this form of energy requires high financial support, technological development, and a competitive structure and strategy. With the development of this type of business partnership, cooperation between various stakeholders is created, both in terms of sharing resources, materials, and equipment, as well as sharing knowledge and other relevant services.

It was found that although geographical proximity is an important point in the interconnection of companies that make up a cluster, the success of this type of agglomeration does not depend exclusively on geographical positioning, but also on the conditions of the sector in question, at the competitive level, technological innovation of products/services, and interaction processes between the various parts that make up the business.

Regarding the port sector, it was inferred that it plays a fundamental role in the Portuguese economy, since it conceives a support to several activities developed in Portugal. In addition, the port aims at local and regional development, as well as the establishment of interconnection points in the logistics and international transport networks. The Port of Aveiro integrates the main port system in Portugal and benefits from several advantages.

The impact of seaports on activities such as offshore wind energy was verified and it was concluded that they are a benefit for the whole production process, since they can help in the transportation of various equipment, but also in the supply chain, through assembly, handling, manufacturing, and transportation. In addition, several ports where this type of activity takes place were studied and it was found that the main ports are in the North Sea and the Baltic Sea, distributed in particular by Germany, Belgium, Denmark, France, the Netherlands, and the United Kingdom.

Regarding the cluster implementation study in the Port of Aveiro, it appeared that the fact that the Port of Aveiro has a large logistics area, a good geographical position, and quality equipment available can be an important advantage for the development of a cluster. However, it is essential that a market research of various types of companies belonging to the sectors that were found to be essential for the creation of the cluster, as well as the development of a structured and coordinated project for a pre-demonstration to these companies. Furthermore, it was inferred that public policies and incentives are important actions in the implementation of this type of project, and that the government plays an important role. 
Moreover, it is considered that the State recognizes the importance of this type of projects for the prospecting of renewable energy and achievement of the targets set against GHG emissions, so it is expected that its support be a long-term project.

\section{Conclusions}

This paper has examined the feasibility of creating an offshore wind cluster in the seaport of Aveiro. It is possible to conclude and infer that the certainty of the viability of the creation of the cluster would only be possible with a communication between the various companies and with a public and financial analysis of the project, but all the analysis carried out in this work points out the Port of Aveiro as an entity in which a cluster of this nature could be viable.

In view of the analysis carried out, it was concluded that the Port of Aveiro presents favorable conditions for the creation of an offshore wind cluster, however, it is essential that a well-designed, coordinated project is established, with a strong strategy and based on the factors presented so that its implementation is possible. It was also possible to infer that the process of forming this type of agglomeration is long, given that it is a project that involves several organizations, high levels of capital, and the creation of trust among stakeholders so that cooperation is stable and obtain the highest performance of the cluster.

Nevertheless, the conclusions related with the development of certain activities in the different seaports, related to the sector under study, were limited, since such information is not found on online platforms and is seen as "confidential". Moreover, there are few projects developed in the same terms approached that allow establishing a comparison.

This piece of research is relevant first, because there is a lack of research that links the importance of the seaports in offshore wind energy projects development, in particular with a cluster structure, and second, because it contributes to knowledge for the leverage of the development of Aveiro region and Portugal, based on the exploitation of the renewable energy market, and to the increase of related activities.

Concerning future investigations, it is important to study the potential companies to be included in this group and the possible financing companies, as well as an analysis of the government's role in implementing these types of initiatives. In addition, studies about geographical agglomerations and understanding whether the location of the cluster's members as well as their proximity influences the success of the cluster should also be relevant. Finally, it is considered that the elaboration of more studies on the creation of offshore wind energy clusters in other regions of Portugal and worldwide would be essential to obtain better conclusions.

Author Contributions: H.J., M.R., and J.C.O.M. conceived and designed the research; H.J. performed the research and the case studies; H.J. and S.G. wrote the paper; M.R. and J.C.O.M. supervised the work; and M.R., J.C.O.M., S.G., and R.G. revised all the document and made valuable suggestions. All authors have read and agreed to the published version of the manuscript.

Funding: This work has been funded by national funds through FCT-Fundação para a Ciência e a Tecnologia, by the research Unit CEBER - I.P., Project UIDB/05037/2020, and by the research unit on Governance, Competitiveness and Public Policy (UIDB/04058/2020), funded by national funds through FCT. Radu Godina acknowledges Fundação para a Ciência e a Tecnologia (FCT-MCTES) for its financial support via the project UIDB/00667/2020 (UNIDEMI).

Institutional Review Board Statement: Not applicable.

Informed Consent Statement: Not applicable.

Data Availability Statement: Not applicable.

Conflicts of Interest: The authors declare no conflict of interest. 


\section{References and Note}

1. BP; Centre for Energy Economics Research and Policy; Heriot-Watt University. BP Statistical Review of World Energy 2019; BP: London, UK, 2019; Volume 225.

2. Dincer, I. Renewable energy and sustainable development: A crucial review. Renew. Sustain. Energy Rev. 2000, 4, 157-175. [CrossRef]

3. Iberdrola O Que é a Energia Eólica Offshore. Available online: https://www.iberdrola.com/meio-ambiente/como-funcionamos-parques-eolicos-offshore (accessed on 3 February 2020).

4. Frisillo, D. An analysis of a potential cluster in an energy sector of Albany, NY. J. Bus. Ind. Mark. 2007, 22, 508-516. [CrossRef]

5. Alrikabi, N. Renewable Energy Types. J. Clean Energy Technol. 2014, 2, 61-64. [CrossRef]

6. Clément, A.; McCullen, P.; Falcão, A.; Fiorentino, A.; Gardner, F.; Hammarlund, K.; Lemonis, G.; Lewis, T.; Nielsen, K.; Petroncini, S.; et al. Wave energy in Europe: Current status and perspectives. Renew. Sustain. Energy Rev. 2002, 6, 405-431. [CrossRef]

7. Bhattacharya, M.; Paramati, S.R.; Ozturk, I.; Bhattacharya, S. The effect of renewable energy consumption on economic growth: Evidence from top 38 countries. Appl. Energy 2016, 162, 733-741. [CrossRef]

8. REN 21. Renewables 2019. Global Status Report; REN: Norfolk, UK, 2019; Volume 8, ISBN 9783981891140.

9. Enerdata Global Energy Statistical Yearbook. 2019. Available online: https://yearbook.enerdata.net/renewables/ (accessed on 10 March 2020).

10. APREN Balanço da Produção de Eletricidade de Portugal Continental. (abril de 2020). Available online: https://www.apren.pt/ pt/energias-renovaveis/producao (accessed on 29 December 2020).

11. Ellabban, O.; Abu-Rub, H.; Blaabjerg, F. Renewable energy resources: Current status, future prospects and their enabling technology. Renew. Sustain. Energy Rev. 2014, 39, 748-764. [CrossRef]

12. Bilgili, M.; Yasar, A.; Simsek, E. Offshore wind power development in Europe and its comparison with onshore counterpart. Renew. Sustain. Energy Rev. 2011, 15, 905-915. [CrossRef]

13. Sahin, A.D. Progress and recent trends in wind energy. Prog. Energy Combust. Sci. 2004, 30, 501-543. [CrossRef]

14. Sims, R.E.H.; Rogner, H.H.; Gregory, K. Carbon emission and mitigation cost comparisons between fossil fuel, nuclear and renewable energy resources for electricity generation. Energy Policy 2003, 31, 1315-1326. [CrossRef]

15. Esteban, M.D.; Diez, J.J.; López, J.S.; Negro, V. Why offshore wind energy? Renew. Energy 2011, 36, 444-450. [CrossRef]

16. DeCastro, M.; Salvador, S.; Gómez-Gesteira, M.; Costoya, X.; Carvalho, D.; Sanz-Larruga, F.J.; Gimeno, L. Europe, China and the United States: Three different approaches to the development of offshore wind energy. Renew. Sustain. Energy Rev. 2019, 109, 55-70. [CrossRef]

17. Komusanac, I.; Brindly, G.; Fraile, D.; Walsh, C.; Wind Europe Business Intelligence. Wind Energy in Europe in 2019: Trends and Statistics; Wind Europe Business Intelligence: Brussels, Belgium, 2019.

18. Colmenar-santos, A.; Perera-perez, J.; Borge-diez, D.; DePalacio-Rodréguez, C. Offshore wind energy: A review of the current status, challenges and future development in Spain. Renew. Sustain. Energy Rev. 2016, 64, 1-18. [CrossRef]

19. Pérez-Collazo, C.; Greaves, D.; Iglesias, G. A review of combined wave and offshore wind energy. Renew. Sustain. Energy Rev. 2015, 42, 141-153. [CrossRef]

20. Perveen, R.; Kishor, N.; Mohanty, S.R. Off-shore wind farm development: Present status and challenges. Renew. Sustain. Energy Rev. 2014, 29, 780-792. [CrossRef]

21. Zountouridou, E.I.; Kiokes, G.C.; Chakalis, S.; Georgilakis, P.S.; Hatziargyriou, N.D. Offshore floating wind parks in the deep waters of Mediterranean Sea. Renew. Sustain. Energy Rev. 2015, 51, 433-448. [CrossRef]

22. Clark, C.E.; DuPont, B. Reliability-based design optimization in offshore renewable energy systems. Renew. Sustain. Energy Rev. 2018, 97, 390-400. [CrossRef]

23. Silva, C.A.S.; Matias, S.; Mafra, C.; Sim-Sim, F.; Estanqueiro, A.; Simões, T.; Justino, P.; Garcia, G.P.; Castro Santos, L.; Sarmento, A.; et al. RoadMap Para as Energias Renováveis Offshore Em Portugal; LNEG/UESEO: Lisboa, Portugal, 2014.

24. Wilkes, J.; Moccia, J. Wind in Power 2012 European Statistics; EWEA: Brussels, Belgium, 2013.

25. Ramírez, L.; Fraile, D.; Brindley, G.; Walsh, C. Offshore Wind in Europe: Key Trends and Statistics 2019; Wind TV: Brussels, Belgium, 2019; Volume 3.

26. Sönnichsen Number of Offshore Wind Farms with Grid-Connected Turbines in European Countries of as 2019. Available online: https:/ / www.statista.com/statistics/666495/number-of-windfarms-eu/ (accessed on 18 May 2020).

27. Durakovic, A. World's Largest Offshore Wind Farm Fully Up and Running. Available online: https://www.offshorewind.biz/20 20/01/30/worlds-largest-offshore-wind-farm-fully-up-and-running/ (accessed on 18 May 2020).

28. EDP WindFloat. Available online: https://www.edp.com/pt-pt/inovacao/windfloat (accessed on 2 April 2020).

29. Ioannou, A.; Vaienti, C.; Angus, A.; Brennan, F. A Cluster Analysis of Investment Strategies in the Offshore Wind Energy Market. In Proceedings of the 2017 6th International Conference on Clean Electrical Power (ICCEP), Santa Margherita Ligure, Italy, 27-29 June 2017; pp. 362-369. [CrossRef]

30. Offshore Ltd. Market Overview Report. Available online: https://www.4coffshore.com/consultancy/MarketAnalysis.aspx (accessed on 20 August 2010).

31. Porter, M.E. Clusters and the New Economics of Competition. Harv. Bus. Rev. 1998, 76, 77-90.

32. Marshall, A. Principles of Economics, 8th ed.; Cosimo, Inc.: London, UK, 2013. 
33. Fundeanu, D.D.; Badele, C.S. The Impact of Regional Innovative Clusters on Competitiveness. Procedia Soc. Behav. Sci. 2014, 124, 405-414. [CrossRef]

34. Fang, K.; Zhou, Y.; Wang, S.; Ye, R.; Guo, S. Assessing national renewable energy competitiveness of the G20: A revised Porter's Diamond Model. Renew. Sustain. Energy Rev. 2018, 93, 719-731. [CrossRef]

35. Zhao, Z.Y.; Hu, J.; Zuo, J. Performance of wind power industry development in China: A DiamondModel study. Renew. Energy 2009, 34, 2883-2891. [CrossRef]

36. Kwek, J.-H.; O’Neil, C.; Satchcroft, A.; Vogt, T. The Australian Renewable Energy Cluster; Harvard Business School: Boston, MA, USA, 2008.

37. Porter, M.E. Competitive Strategy: Techniques for Analyzing Industries and Competitors, Illustrated ed.; Free Press: New York, NY, USA, 1998; ISBN 978-0-684-84148-9.

38. Lages, V.N. Territórios em Movimento: Cultura e Identidade como Estratégia de Inserção Competitiva; SEBRAE: Rio de Janeiro, Brazil, 2004; ISBN 978-85-7316-383-4.

39. Jacobsson, S.; Bergek, A. Transforming the energy sector: The evolution of technological systems in renewable energy technology. Ind. Corp. Chang. 2004, 13, 815-849. [CrossRef]

40. Pego, A. Sistemas e Tecnologias de Informação no Turismo em Espaço Rural: Estudo da Região Algarve. Master's Thesis, Universidade NOVA de Lisboa, Lisbon, Portugal, 2014.

41. Pego, A. Os Sistemas e Tecnologias de Informação e os Clusters. Uma Abordagem ao Cluster de Energia Offshore em Portugal In Proceedings of the Atas das Conferências IADIS Ibero-Americanas www/Internet 2016 e Computação Aplicada 2016, Lisbon, Portugal, 1-13 December 2016.

42. Wind Europe. A Statement from the Offshore Wind Ports; Wind Europe: Bruxelas, Bélgica, 2017.

43. Enamorado, C. The Role of Ports in the Offshore Wind Energy Sector. Available online: https://blog.ferrovial.com/en/2016/03/ ports-in-the-offshore-wind-energy-sector/ (accessed on 29 March 2020).

44. Offshore WIND Staff Port of Rostock: Serving the Baltic Sea. Available online: https://www.offshorewind.biz/2012/08/17/portof-rostock-serving-the-baltic-sea/ (accessed on 29 March 2020).

45. Economic Development Agency Offshore Base Cuxhaven. Available online: https://en.offshore-basis.de/ (accessed on 29 March 2020).

46. Port Oostende Port Activities. Available online: https://www.portofoostende.be/ (accessed on 29 March 2020).

47. Port of Zeebrugge Wind Energy. Available online: https://portofzeebrugge.be/en/port/sustainability/wind-energy (accessed on 29 March 2020).

48. Port Esbjerg Wind. Available online: https://portesbjerg.dk/en/business-area/renewables (accessed on 29 March 2020).

49. Gisselbaek, T. Wind. Available online: https://www.port-of-grenaa.com/Core-segments/Wind/ (accessed on 29 March 2020).

50. Cour, J. Offshore Wind. Available online: https://www.roennehavn.dk/en/business-areas/offshore-wind/ (accessed on 29 March 2020).

51. Bilbao Port Port of bilbao Receives First Offshore Wind Turbine Operation. Available online: https://www.bilbaoport.eus/en/ news / port-of-bilbao-receives-first-offshore-wind-turbine-operation/ (accessed on 29 March 2020).

52. Port of Dieppe Normandy, $\mathrm{N}^{\circ} 1$ Region in France for the Development of Offshore Wind Power. Available online: http: / / www.portdedieppe.fr/-Offshore-Wind-.html?lang=fr (accessed on 29 March 2020).

53. Hidrio, M. Marine Renewable Energies. Available online: https://www.lehavreseinedeveloppement.com/en/sectors-markets/ marine-renewable-energies (accessed on 29 March 2020).

54. Port de Rouen Renewable Energies. Available online: https://www.haropaports.com/en/rouen/renewable-energies (accessed on 29 March 2020).

55. Port of Amsterdam Offshore Wind. Available online: https://www.portofamsterdam.com/en/business/cargo/offshore-wind (accessed on 29 March 2020).

56. Russel, G. Offshore Wind. Available online: https:/ /www.abports.co.uk/services/offshore-wind/ (accessed on 29 March 2020).

57. Offord, R. About Green Port Hull. Available online: https://greenporthull.co.uk/about-green-port (accessed on 29 March 2020).

58. Port of Blyth Energy Sector. Available online: http:/ / portofblyth.co.uk/energy-sector/ (accessed on 29 March 2020).

59. Autoridade da Concorrência. Estudo Sobre Concorrência No Setor Portuário; Autoridade da Concorrência: Lisbon, Portugal, 2018.

60. Semedo, D.E.M. Avaliação da Implementação da Energia Eólica Offshore em Cabo Verde. Master's Thesis, Escola Superior de Tecnologia e Gestão do Instituto Politécnico de Leiria, Leiria, Portugal, 2018.

61. Ocean Energy Forum. Ocean Energy Strategic Roadmap: Building Ocean Energy for Europe; Ocean Energy Forum: Bristol, UK, 2016.

62. GP WIND. GP WIND-Good Practice Guide; GP WIND: Hyderabad, India, 2013.

63. Cox, S.; Tegen, S.; Baring-Gould, I.; Oteri, F.A.; Esterly, S.; Forsyth, T.; Team, W.A.; Baranowski, R. Policies to Support Wind Power Deployment: Key Considerations and Good Practices. Clean Energy Solut. Cent. 2015. [CrossRef]

64. Porto de Aveiro Instalações Portuárias. Available online: https://portodeaveiro.pt/instalacoes-portuarias/pt/ (accessed on 29 March 2020).

65. ASM Industries Fundações Offshore. Available online: https://asm-industries.com/pt-pt/fundacoes-offshore/ (accessed on 29 March 2020).

66. ASM Industries Torres Eólicas. Available online: https://asm-industries.com/pt-pt/torres-eolicas/ (accessed on 29 March 2020).

67. Lines, T.; Monypenny, R. Industrial Clustering; James Cook University: Townsville, Australia, 2018. 
68. Support, C.C.; Report, C.D.; No, C. Guidelines for Cluster Development; Maxwell Stamp: London, UK, 2013.

69. Reveiu, A.; Dârdală, M. Influence of cluster type business agglomerations for development of entrepreneurial activities study about Romania. Amfiteatru Econ. 2015, 17, 107-119.

70. Yüksel, I. Developing a Multi-Criteria Decision Making Model for PESTEL Analysis. IJBM 2012, 7, 52. [CrossRef]

71. Salvarli, M.S.; Kayışkan, D. An Analysis of McKinsey 7-S Model and Its Application on Organizational Efficiency. Int. J. Sci. Technol. Res. 2018, 4, 2422-8702.

72. Gokdeniz, I.; Kartal, C.; Komurcu, K. Strategic Assessment based on 7S McKinsey Model for a Business by Using Analytic Network Process (ANP). IJARBSS 2017, 7, 342-353. [CrossRef]

73. Sarsby, A. SWOT Analysis, 1st ed.; Spectaris Ltd.: Stowmarket, UK, 2016; ISBN 978-0-9932504-2-2.

74. Pahl, N.; Richter, A. Swot Analysis Idea, Methodology and a Practical Approach; GRIN Verlag: Munich, Germany, 2009; ISBN 978-3-640-30303-8.

75. Calicchio, S. SWOT Analysis in 4 Steps: How to Use the SWOT Matrix to Make a Difference in Career and Business; Calicchio, S., Ed.; Amazon: Seattle, WA, USA, 2020; ISBN 978-88-358-4104-3.

76. Junqueira, H. Viabilidade do Cluster de Energia Eólica Offshore no Porto de Aveiro. In The Master's in Sustainable Energy Systems; Universidade de Aveiro: Aveiro, Portugal, 2020.

77. AIDA Vantagens Competitivas da Região de Aveiro. Available online: http:/ /aida.pt/regiao/vantagens-competitivas-da-regiao. html (accessed on 29 March 2020). 